\title{
Kikuyu (Pennisetum clandestinum) intake determined by alkanes administered in a xantham gum suspension
}

\author{
J. Mann ${ }^{\#}$ and P.G. Stewart \\ KwaZulu-Natal Department of Agriculture and Environmental Affairs, \\ Private Bag X 9059, Pietermaritzburg 3200, South Africa
}

\begin{abstract}
The alkane method of measuring herbage intake in ruminants was compared with actual intake determined by transponder-controlled feed gates (Calan gates). Kikuyu (Pennisetum clandestinum) intakes of yearling bulls (Holstein-Friesland and Hereford) were measured for a period of seven days. No significant effect of breed on intake was found. Herbage intake calculated from the alkane technique (mean of morning and afternoon faecal sampling times) compared favourably with actual intake with an average intake of $6.25 \mathrm{~kg} \mathrm{DM} /$ day (93 g DM/kg W${ }^{0.75} /$ day) ( $\mathrm{CV} \mathrm{22 \% ).} \mathrm{However,} \mathrm{a} \mathrm{significant} \mathrm{effect} \mathrm{in} \mathrm{the} \mathrm{faecal} \mathrm{sampling}$ times on intake was observed. Herbage intake determined from alkane concentrations in the faecal samples that were collected in the morning underestimated actual intake by $11 \%$, while intake calculated from faecal alkane concentrations of samples that were collected in the afternoon overestimated actual intake by $8 \%$. It is hypothesised from this study that the dosing of the alkane (dotriacontane) should be every 12 hours when administered in a xantham gum suspension.
\end{abstract}

Keywords: Alkanes, intake, kikuyu, ruminant

${ }^{\#}$ Corresponding author. E-mail: joanne.mann@dae.kzntl.gov.za

\section{Introduction}

The alkane technique (Dove \& Mayes, 1991; 1996) has been widely used to estimate individual herbage intake (and digestibility) of ruminants. Intake is determined by the ratio of the orally administered synthetic alkane (dotriacontane) to the naturally occurring alkane (tritriacontane). Although herbage intake measured by the alkane method has an error of less than 5\% (Dove \& Mayes, 1991) when compared with actual intake, most of these validation studies were done on either perennial ryegrass (Lolium perenne) or natural pasture (mostly Festuca species). Various studies have been conducted using the alkane technique to measure intake on kikuyu (Pennisetum clandestinum), but either actual intake was not measured (Horne, 1996; Reeves et al., 1996b; Fushai, 1997) or time of faecal sampling was not considered (Reeves et al., 1995). Various methods of alkane administration to the ruminant have been used. These include: controlled release devices (Reeves et al., 1995), gelatine capsules (Reeves et al., 1996b; Dove et al., 2000), pellets (Hameleers \& Mayes, 1998) and a suspension (Horne, 1996; Marais et al., 1996; Fushai, 1997). The studies that have used the suspension prepared by Marais (Marais et al., 1996) did not measure actual intake of kikuyu. The aim of this study was to assess how the alkane intake estimate (using the suspension by Marais et al., 1996) would compare with actual intake on kikuyu.

\section{Material and Methods}

The dry matter (DM) intake of nine yearling bulls (five Hereford and four Holstein-Friesland) was measured in a Calan gate facility (transponder-controlled feed gate; described by Broadbent et al., 1970) to compare with alkane intake estimates over a period of seven days (following 30 days of adaptation).

Animals had ad libitum access to cut kikuyu grass and a mineral supplement. The grass was cut daily to a residual height of $40 \mathrm{~mm}$ with a sickle bar mower. The herbage was further chopped with a forage harvester to a length of $c a .25 \mathrm{~mm}$ to prevent wastage. The herbage was weighed in and out of feed troughs daily.

The animals were orally administered $1 \mathrm{~g}$ of dotriacontane daily at 6:00. The dotriacontane was coated onto dried milled kikuyu suspended in a $0.4 \%$ xantham gum solution, using a rotary evaporator (Marais et $a l .$, 1996). Faecal samples (to be analysed for dotriacontane $\left(\mathrm{C}_{32}\right)$ and tritriacontane $\left(\mathrm{C}_{33}\right)$ concentration) were collected from the rectum of each animal daily at 6:00 and 18:00. 
Kikuyu grass samples were analysed for crude protein (AOAC, 1995; method 990.03), acid detergent fibre (AOAC, 1995; method 973.18), neutral detergent fibre (Van Soest et al., 1991), ash (AOAC, 1990; method 942.05), calcium (AOAC, 1995; method 968.08) and phosphorus (AOAC, 1990; method 965.17).

The alkane concentration of the coated grass (administered orally), kikuyu grass and faecal samples was analysed for dotriacontane $\left(\mathrm{C}_{32}\right)$ and tritriacontane $\left(\mathrm{C}_{33}\right)$ concentrations, according to Marais' procedure (Marais et al., 1996) with some modifications (J.P. Marais, 1997, KwaZulu-Natal Department of Agriculture and Environmental Affairs, Pietermaritzburg. Pers. comm.) which are summarized in Table 1. Samples were not analysed in duplicate as in the procedure by Marais et al. (1996) because of cost. The internal standard was changed from tetratriacontane $\left(C_{34}\right)$, which was used in Marais et al. (1996) to hexatriacontane $\left(C_{36}\right)$.

Table 1 Modifications made to Marais' procedure (Marais et al., 1996) (J.P. Marais, 1997, Pers. comm.)

\begin{tabular}{|c|c|c|}
\hline Measurement & Marais et al. (1996) & Current study \\
\hline \multicolumn{3}{|l|}{ Coating of dotriacontane onto solid support } \\
\hline Milled grass particle size & 0.5 to $1.0 \mathrm{~mm}$ & $0.5 \mathrm{~mm}$ \\
\hline Rotary evaporator temperature during $\mathrm{C}_{32}$ coating onto grass support & $40^{\circ} \mathrm{C}$ & $60^{\circ} \mathrm{C}$ \\
\hline Coated grass sieved to remove lumps & $1 \mathrm{~mm}$ sieve & $0.5 \mathrm{~mm}$ sieve \\
\hline \multicolumn{3}{|l|}{ Dotriacontane coated grass analysis } \\
\hline Quantity of petroleum ether $\left(80-100^{\circ} \mathrm{C} \mathrm{BP}\right)$ added to coated grass sample & $30 \mathrm{~mL}$ & $40 \mathrm{~mL}$ \\
\hline Quantity of solvent added to silica gel column to elute alkanes & $10 \mathrm{~mL}$ hexane & $\begin{array}{l}25 \mathrm{~mL} \text { petroleum } \\
\text { ether }\left(60-80^{\circ} \mathrm{C} \mathrm{BP}\right)\end{array}$ \\
\hline \multicolumn{3}{|l|}{ Grass analysis } \\
\hline Quantity of grass analysed & - & $1.5 \mathrm{~g}$ \\
\hline \multicolumn{3}{|l|}{ Faecal analysis } \\
\hline Quantity of solvent added to silica gel column to elute alkanes & $10 \mathrm{~mL}$ hexane & $\begin{array}{l}25 \mathrm{~mL} \text { petroleum } \\
\text { ether }\left(60-80{ }^{\circ} \mathrm{C} \mathrm{BP}\right)\end{array}$ \\
\hline $\begin{array}{l}\text { Quantity of hexane in which the extracted alkanes were dissolved (before } \\
\text { injected into gas chromatograph) }\end{array}$ & $0.3 \mathrm{~mL}$ & $0.7 \mathrm{~mL}$ \\
\hline
\end{tabular}

Grass and faecal alkane (dotriacontane and tritriacontane) concentrations were substituted in the equation by Dove \& Mayes (1991) to calculate intake:

$$
\text { Intake }\left(\frac{\mathrm{kg} \mathrm{DM}}{\mathrm{d}}\right)=\frac{\frac{\mathrm{Fi}}{\mathrm{Fj}} \times \mathrm{Dj}}{\mathrm{Hi}-\left(\frac{\mathrm{Fi}}{\mathrm{Fj}} \times \mathrm{Hj}\right)}
$$

where

$\mathrm{Dj}=$ daily dose of the even-chain alkane $\left(\mathrm{C}_{32}\right)$

$\mathrm{Fi}$ = faecal concentrations of the odd-chain alkane $\left(\mathrm{C}_{33}\right)$

$\mathrm{Hi}=$ herbage concentrations of the odd-chain alkane $\left(\mathrm{C}_{33}\right)$

$\mathrm{Fj}=$ faecal concentrations of the even-chain alkane $\left(\mathrm{C}_{32}\right)$

$\mathrm{Hj}=$ herbage concentrations of the even-chain alkane $\left(\mathrm{C}_{32}\right)$.

Statistical differences between treatment means for intake were determined from analysis of variance tables (Genstat 5 (Release 3.2) statistical program) using least significant differences. 


\section{Results and Discussion}

The chemical analysis of the herbage fed is given in Table 2. The low crude protein, high neutral detergent fibre and high acid detergent fibre values of the herbage on offer, when compared with the studies by Reeves et al. (1996a) and Dugmore (1998) indicate that it was either very mature kikuyu (high stem fraction) or nitrogen fertilization may have been lacking (T.J. Dugmore, 2000, KwaZulu-Natal Department of Agriculture and Environmental Affairs, Pietermaritzburg. Pers. Comm.)

Table 2 Mean chemical composition $(\mathrm{g} / \mathrm{kg} \mathrm{DM})$ of the daily kikuyu on offer $(\mathrm{n}=8)$ compared with two studies from the literature (Reeves et al., 1996a; Dugmore, 1998)

\begin{tabular}{lccc}
\hline Measurement & Herbage & Reeves et al. (1996a) & Dugmore (1998) \\
\hline Crude protein (g/kg DM) & 87.6 & 207.5 & 200 \\
\pm s.e. & \pm 4.6 & 602.5 & 650 \\
Neutral detergent fibre (g/kg DM) & 709.3 & & \\
\pm s.e. & \pm 13.6 & 230.9 & 350 \\
Acid detergent fibre (g/kg DM) & 390.7 & & \\
\pm s.e. & \pm 8.8 & & \\
Ash $(\mathrm{g} / \mathrm{kg} \mathrm{DM})$ & 84.9 & 3.1 & 2.4 \\
\pm s.e. & \pm 4.3 & & 3.3 \\
Calcium $(\mathrm{g} / \mathrm{kg} \mathrm{DM})$ & 4.1 & 3.1 & \\
\pm s.e. & \pm 0.2 & & \\
Phosphorus (g/kg DM) & 2.2 & & \\
\pm s.e. & \pm 0.1 & & \\
\hline
\end{tabular}

Actual and alkane estimated kikuyu intake is presented in Table 3. No significant effect of breed on intake was measured; therefore, the data was pooled.

Table 3 Actual and calculated intake (alkane technique) of cut kikuyu herbage of yearling bulls

\begin{tabular}{|c|c|c|c|c|c|}
\hline \multirow[b]{2}{*}{ Measurement } & \multirow{2}{*}{$\begin{array}{l}\text { Actual intake } \\
(n=9)\end{array}$} & \multicolumn{3}{|c|}{ Herbage intake calculated by the $\mathrm{C}_{33}-\mathrm{C}_{32}$ alkane pair } & \multirow[b]{2}{*}{$\mathrm{CV} \%$} \\
\hline & & $\begin{array}{l}\text { Mean } \\
(\mathrm{n}=9)\end{array}$ & $\begin{array}{l}\text { Morning }^{\mathrm{s}} \\
(\mathrm{n}=9)\end{array}$ & $\begin{array}{l}\text { Afternoon }{ }^{\mathrm{s}} \\
(\mathrm{n}=9)\end{array}$ & \\
\hline $\begin{array}{l}\text { Intake }(\mathrm{kg} \mathrm{DM} / \mathrm{d}) \\
\pm \text { s.e. }\end{array}$ & $\begin{array}{l}6.28^{\mathrm{b}} \\
\pm 0.24\end{array}$ & $\begin{array}{l}6.21^{\mathrm{b}} \\
\pm 0.15\end{array}$ & $\begin{array}{l}5.61^{\mathrm{a}} \\
\pm 0.17\end{array}$ & $\begin{array}{l}6.81^{\mathrm{c}} \\
\pm 0.22\end{array}$ & 23 \\
\hline $\begin{array}{l}\text { Intake }\left(\mathrm{g} \mathrm{DM} / \mathrm{kg} \mathrm{W}^{0.75} / \mathrm{d}\right) \\
\pm \text { s.e. }\end{array}$ & $\begin{array}{l}93.6^{\mathrm{b}} \\
\pm 3.16\end{array}$ & $\begin{array}{l}92.9^{\mathrm{b}} \\
\pm 2.07\end{array}$ & $\begin{array}{l}83.7^{\mathrm{a}} \\
\pm 2.17\end{array}$ & $\begin{array}{l}102.2^{\mathrm{c}} \\
\pm 3.12^{2}\end{array}$ & 22 \\
\hline
\end{tabular}

$\mathrm{a}, \overline{b, c}$ Values bearing different superscripts in the same row are significantly different $(\mathrm{P}<0.05)$

${ }^{\mathrm{s}}$ Intake determined from faecal samples collected at either 06:00 or 18:00

Although the intake of kikuyu herbage calculated by the alkane technique did not differ from actual intake when the sampling times were combined, significant trends were found when analysed for time of day. Herbage intake calculated from the $\mathrm{C}_{33}-\mathrm{C}_{32}$ concentrations in the morning faecal samples resulted in actual intake being underestimated by $11 \%(\mathrm{P}<0.05)$ while herbage intake calculated from alkane concentrations in the afternoon faecal samples overestimated actual intake by $8 \%(\mathrm{P}<0.05)$. Literature on the alkane method of intake estimation recommended that faecal sampling could be done once a day since the variability of the faecal $\mathrm{C}_{33}: \mathrm{C}_{32}$ ratio is less than $5 \%$ when expressed as a proportion of the mean (Mayes et al., 1986b). Only nine of the 15 points of the current study fell within the $5 \%$ range when expressed as a proportion of the mean. An analysis of variance was conducted on the $\mathrm{C}_{33}: \mathrm{C}_{32}$ ratio and confirmed the significant difference (differed by $18 \% ; \mathrm{P}<0.05$ ) between the morning and afternoon $\mathrm{C}_{33}: \mathrm{C}_{32}$ ratio and consequently intake estimates.

It is unlikely that the effect of the faecal sampling time (06:00 and 18:00) on intake could be attributed to diurnal variation as the alkane method has been used previously to predict intake accurately (Mayes et al., 1986a, b; Dillon \& Stakelum, 1989; Reeves et al., 1995). 
Reeves et al. (1996b) compared the alkane method with the rising plate meter and the standard energy requirements in reverse to determine kikuyu intake of dairy cows. Although Reeves et al. (1996b) concluded that the alkane method is a "direct and precise method of measuring the intake of individual cows grazing tightly-managed kikuyu pasture", actual intake was not measured. Furthermore, Reeves et al. (1996b) did not find a significant difference in intake determined by the morning (06:00) and afternoon (14:00) sampling times (eight hour interval). Hard-shell gelatine capsules containing alkanes were embedded in powdered cellulose, were administered twice a day in Reeves' study.

In the study by Hameleers \& Mayes (1998), dairy cows were administered alkane pellets (containing dotriacontane) twice a day and faecal samples were collected twice a day after milking (times were not stipulated). The herbage consumed was perennial ryegrass (Lolium perenne) and white clover (Trifolium repens). No significant effect $(\mathrm{P}>0.05)$ was detected in intake determined by morning and afternoon sampling times and actual intake.

A study (Dove et al., 2000) where dosing (alkane capsules) and faecal collection times were carried out twice a day (09:00 and 16:00; seven hour interval) using sheep, similarly found no difference in alkane concentration (hence intake) between twice a day faecal grab samples and total faecal collection (determined by faecal bags). The herbage on offer was temperate pasture.

Although the actual kikuyu intake measured by Reeves et al. (1995) did not differ significantly from intake calculated by the $\mathrm{C}_{32}-\mathrm{C}_{33}$ alkane pair, time of faecal sampling was not investigated. Faecal samples were collected twice daily but were pooled across days. The success of the alkane technique in the study by Reeves et al. (1995) might be attributed to the method of alkane administration, which was a controlled release device.

Besides the study by Reeves et al. (1995) no other studies on kikuyu, which also compared the alkane technique with actual intake were found in the literature. The findings of the current paper might possibly be explained by the dosing schedule as opposed to the faecal sampling schedule. From the alkane studies mentioned in the literature, the dosed alkane (usually dotriacontane) was administered twice a day either in capsule (Reeves et al., 1996b; Dove et al., 2000), in pellet form (Hameleers \& Mayes, 1998) or continuously by a controlled release device (Reeves et al., 1995). The variability of the $\mathrm{C}_{33}: \mathrm{C}_{32}$ ratio between the morning and afternoon faecal sampling times of the current study could be due to the dotriacontane concentration varying in the rumen. Another dose of dotriacontane is possibly required within a 24 hour period to maintain a continuous flow of dotriacontane through the digestive tract. Although once a day dosing and faecal sampling has been accepted as adequate when using the alkane technique (Mayes et al., 1986b), it can be hypothesised from this study that the dosing of the alkane (dotriacontane) should be every 12 hours when administered in a xantham gum suspension. The faecal sampling schedule requires further investigation.

\section{Conclusion}

From this study it is hypothesised that the dosing of the alkane (dotriacontane) should be every 12 hours when administered in a xantham gum suspension, as described by Marais et al. (1996).

\section{Acknowledgements}

The authors would like to acknowledge and thank the following persons for making this trial possible: the Animal Science Section at Cedara for the use of the bulls, kikuyu pastures and Calan gate facility, particularly B. Zondi and his team; the Biochemistry Section at Cedara, especially J.P. Marais for instruction concerning the alkane technique and for the use of the laboratory; C. Stevens and M.I. Whitwell for biometrical analyses.

\section{References}

AOAC, 1990. Official methods of analysis of AOAC International (15th ed.). Ed. Helrich, K., Association of Official Analytical Chemists, Arlington, Virginia, USA, Volume 1.

AOAC, 1995. Official methods of analysis of AOAC International (16th ed.). Ed. Cunniff, P., Association of Official Analytical Chemists, Gaithersburg, Maryland, Volume 1.

Broadbent, P.J., McIntosh, J.A.R. \& Spence, A., 1970. The evaluation of a device for feeding group-housed animals individually. Anim. Prod. 12, 245-252. 
Dillon, P. \& Stakelum, G., 1989. Herbage and dosed alkanes as a grass measurement technique for dairy cows. Ir. J. Agric. Res. 28, 104.

Dove, H., Freer, M. \& Foot, J.Z., 2000. The nutrition of grazing ewes during pregnancy and lactation: a comparison of alkane-based and chromium/in vitro-based estimates of herbage intake. Aust. J. Agric. Res. 51, 765-777.

Dove, H. \& Mayes, R.W., 1991. The use of plant wax alkanes as marker substances in studies of the nutrition of herbivores: A review. Aust. J. Agric. Res. 42, 913-952.

Dove, H. \& Mayes, R.W., 1996. Plant wax components: A new approach to estimating intake and diet composition in herbivores. J. Nutr. 126, 13-26.

Dugmore, T.J., 1998. Energy and mineral content. In: Proc. Kikuyu Technology Day. Ed. Batholomew, P.E., KwaZulu-Natal Department of Agriculture, Directorate of Technology Development and Training, Pietermaritzburg. pp. 12-14.

Fushai, F.M., 1997. An investigation into growth in Jersey, Holstein and Hereford heifers on kikuyu pasture (Pennisetum clandestinum) using n-alkanes to estimate intake and ruminal outflow rate. MSc (Agric) thesis, University of Natal, South Africa.

Genstat, 1995. Genstat 5, Release 3.2 Reference Manual. Lawes Agricultural Trust, Rothamsted Experimental Station, Clarendon Press, Oxford.

Hameleers, A. \& Mayes, R.W., 1998. The use of $n$-alkanes to estimate herbage intake and diet composition by dairy cows offered a perennial ryegrass/white clover mixture. Grass Forage Sci. 53,164-169.

Horne, T., 1996. An investigation into growth in heifers on kikuyu pasture (Pennisetum clandestinum) using n-alkanes to measure intake and digestibility. MSc (Agric) thesis, University of Natal, South Africa.

Marais, J.P., Figenschou, D.L., Escott-Watson, P.L. \& Webber, L.N., 1996. Administration in suspensionform of n-alkane external markers for dry matter intake and diet selection studies. J. Agric. Sci., Camb. $126,207-210$.

Mayes, R.W., Lamb, C.S. \& Colgrove, P.M., 1986a. Determination of herbage intake of sucking lambs using long-chain n-alkanes as markers. Anim. Prod. 42, 457 (Abstr.).

Mayes, R.W., Lamb, C.S., \& Colgrove, P.M., 1986b. The use of dosed and herbage n-alkanes as markers for the determination of herbage intake. J. Agric. Sci., Camb. 107, 161-170.

Reeves, M., Fulkerson, W.J., \& Kellaway, R.C., 1995. The relative accuracy of estimating intake and digestibility of kikuyu grass pasture using plant wax alkanes. In: NSW Agriculture Dairy Research Institute. Incorporating dairy research at Wollongbar, Camden, Wagga, Berry, Taree. Ed. Fulkerson, W.J. p.p. 30-32.

Reeves, M., Fulkerson, W.J., \& Kellaway, R.C., 1996a. Forage quality of kikuyu (Pennisetum clandestinum): the effect of time of defoliation and nitrogen fertilizer application and in comparison with perennial ryegrass (Lolium perenne). Aust. J. Agric. Res. 47, 1349-1359.

Reeves, M., Fulkerson, W.J., Kellaway, R.C. \& Dove, H., 1996b. A comparison of three techniques to determine herbage intake of dairy cows grazing kikuyu (Pennisetum clandestinum) pasture. Aust. J. Exper. Agric. 36, 23-30.

Van Soest, P.J., Robertson, J.B. \& Lewis, B.A., 1991. Methods for dietary fiber, neutral detergent fiber, and nonstarch polysaccharides in relation to animal nutrition. J. Dairy Sci. 74, 3583-3597. 